\title{
Partnership
}

Canadian journal of library and information practice and research

Revue canadienne de la pratique et de la recherche en bibliothéconomie et sciences de

l'information

\section{Book Review: Academic Libraries and Public Engagement with Science and Technology}

\section{Scott Turner}

Volume 16, numéro 1, 2021

Special Issue on Libraries and the Pandemic

Numéro spécial sur les bibliothèques et la pandémie

URI : https://id.erudit.org/iderudit/1078575ar

DOI : https://doi.org/10.21083/partnership.v16i1.6449

Aller au sommaire du numéro

Éditeur(s)

The Partnership: The Provincial and Territorial Library Associations of Canada

ISSN

1911-9593 (numérique)

Découvrir la revue

Citer ce compte rendu

Turner, S. (2021). Compte rendu de [Book Review: Academic Libraries and Public Engagement with Science and Technology]. Partnership, 16(1), 1-3.

https://doi.org/10.21083/partnership.v16i1.6449 


\section{PARTNERSHIP}

The Canadian Journal of Library and Information Practice and Research

Revue canadienne de la pratique et de la recherche en bibliothéconomie et sciences de linformation

vol. 16, no. 1 (2021)

Book Review (editorially reviewed)

DOI: https://doi.org/10.21083/partnership.v16i1.6449

CC BY-NC-ND 4.0

\section{Harrington, E. G. (2019). Academic libraries and public engagement with science and technology. Chandos Publishing.}

This book delivers what the title suggests: a variety of strategies for academic libraries to engage their users and the general public with science and emerging technologies. It achieves this with two approaches: the first, by discussing a topic-whether it be citizen science or open science-and second, by describing numerous real-world case studies for each. The intended audience is primarily academic librarians in the STEM (science, technology, engineering, and mathematics) disciplines.

Value will be found for new STEM librarians looking to begin outreach initiatives, and for established STEM librarians seeking new ideas or alternative approaches to engagement. Of additional value are quotations from the librarians involved in case studies throughout the text, providing insight into how initiatives were developed and what impact they had. Not only will readers find new ideas to serve their communities, learn about creative uses of library spaces, but they will also gain insight into collaborating with faculty in helping to share their research with the broader community.

Author Eileen Harrington is the Health \& Life Sciences Librarian and Assistant Director of the Priddy Library with the Universities at Shady Grove, Maryland. She holds a Bachelor of Arts degree in Environmental Studies and Biology, Master's degree in Environmental Studies, and Master's degree in Library and Information Studies. Prior to her current role, she oversaw the Naturalist Center at the California Academy of Sciences in San Francisco. She has authored several publications including her previous book, Exploring Environmental Science with Children and Teens which was published in 2014.

Academic Libraries and Public Engagement with Science and Technology was published in 2019 and includes seven chapters, beginning with an introduction to the state of science literacy across the United States-although many of the same trends apply to Western countries generally. Harrington discusses the degree of science literacy among different demographics and rising science skepticism in the context of important global issues like health and environment. This sets the stage for the rest of 
the book in how academic libraries can foster science literacy and provide venues for scientists to communicate their research.

Chapter 2 addresses how users can take a hands-on approach to learning through makerspaces in libraries. Advances in technologies, reductions in costs, and the growth of open source software have all set the stage for makerspaces, which reflect the core values of a library including access to resources, opportunities for cross-disciplinary collaboration, and self-directed learning. Harrington provides details on the logistics of establishing a makerspace along with considerations for campus partners, staff training, and ideas for marketing and programming. This leads into the next couple of chapters which focus on programming and outreach more broadly. Numerous case studies demonstrate different approaches libraries have taken to foster science literacy including STEM graphic novels, outreach to K-12 students, science speed dating to succinctly communicate research, projects to edit Wikipedia, and more. Faculty-led discussions open to the public about the science in science fiction literature and movies make scientific concepts more relatable, inspiring young people to consider pursuing a career in the STEM fields. Developing relationships with local businesses and organizations are additional means of outreach. For example, offering patent workshops to local business startups can be a way to engage with the broader community.

The last three chapters discuss growing trends that academic librarians are actively participating in-namely, citizen science, data services, and open science. Citizen scientists are those who may or may not have a background in science but can still participate in scientific research, allowing them a stake in the results. Advancing technologies allow the public to collect vast amounts of data about themselves and their environment. This data can be shared with researchers, allowing for much larger pools of data collection than traditional studies could afford-from human health to environmental data to mapping-individuals can collect, share, and even help clean and analyze large sets of data. Librarians can contribute with outreach and by providing guidance in data management, as well as loaning the out the actual technology for data collection. Data librarians are playing ever greater roles in the data life cycle, including helping researchers with planning, collecting, analyzing, cleaning, sharing, and preserving their data. They can support researchers through data management plans, assist with funding proposals, and offer guidance on how sensitive data should be stored. All of this leads to open science, which is freely accessible open content, carried out through open processes, and supported by open infrastructures. Barriers to open science like funding and protecting sensitive data are discussed, but Harrington emphasizes the benefits, including increased collaboration, equitable access, greater accountability, and librarians supporting faculty who produce open educational resources like open textbooks and tutorials. Two thorough case studies exemplifying the roles librarians can play round out the chapter, with a focus on open access journals and institutional repositories.

In addition to discussing the variety of approaches for engaging users in science and technology, the case studies are particularly helpful in illustrating actual outreach and engagement initiatives. This practical format makes the book a useful and versatile resource suitable for different institutions and approaches. For STEM librarians in 
search of new ideas and opportunities for outreach, Harrington offers a number of examples to consider with extensive reference lists at the end of each chapter. Although it is a good idea to start with the introductory chapter, subsequent chapters are selfcontained and so it's possible to skip ahead to a chapter of interest and come back to previous chapters at a later time.

In summary, Academic Libraries and Public Engagement with Science and Technology delivers what its title promises, with distinct chapters allowing the reader to navigate toward what interests them most and find a comprehensive discussion of the topic, supplemented by numerous case studies.

Scott Turner

STEM Librarian

MacOdrum Library

Carleton University

Ottawa, ON

scott.turner@carleton.ca 